\title{
THE Cd:Zn RATIO IN A SOIL AFFECTS Cd TOXICITY IN SPINACH (Spinacea oleracea L.)
}

\author{
Tajammal Hussain ${ }^{1, *}$, Ghulam Murtaza ${ }^{1}$, Abdul Ghafoor ${ }^{1}$ and Mumtaz Akhtar Cheema ${ }^{2}$ \\ ${ }^{1}$ Institute of Soil and Environmental Sciences, University of Agriculture, Faisalabad-38040, Pakistan \\ ${ }^{2}$ Department of Agronomy, University of Agriculture, Faisalabad-38040, Pakistan \\ "Corresponding author's email: tjhussainuaf@gmail.com
}

\begin{abstract}
Cadmium (Cd) is a highly soil mobile heavy metal which is toxic even at very low concentrations and is thus of potential human health concern due to its entry into the food chain via consumption of edible crops. The plant nutrition is the most economical and practicable method among all strategies for reducing the accumulation of $\mathrm{Cd}$ in the edible parts of the plants. This experiment investigated the effect of changing the $\mathrm{Cd}$ :zinc $(\mathrm{Zn})$ ratio in the soil in order to minimize the accumulation of $\mathrm{Cd}$ in the edible parts, i.e. the leaves of spinach. Overall spinach growth was decreased in $\mathrm{Cd}$ contaminated soil, and $\mathrm{Cd}$ concentrations in spinach leaf increased with increased exposure to $\mathrm{Cd}$. However, while spinach growth increased at a moderate $\mathrm{Cd}: \mathrm{Zn}$ ratio of 1:10, at higher $\mathrm{Zn}$ soil concentrations $(\mathrm{Cd}: \mathrm{Zn}=1: 100)$ plant growth was decreased, but this was also accompanied by a significantly decreased $(\mathrm{P}<0.05)$ in the accumulation of $\mathrm{Cd}$ the spinach leaves. Thus the ratio of $\mathrm{Cd}: \mathrm{Zn}$ in $\mathrm{Cd}$ contaminated soils can simultaneously decrease the adverse effects of $\mathrm{Cd}$ on plant growth and also minimize $\mathrm{Cd}$ uptake into edible plant parts.

Keywords: Cadmium, toxicity, cadmium: zinc, vegetables, health risks.
\end{abstract}

\section{INTRODUCTION}

The current population of Pakistan is almost 192 million (Economic Survey of Pakistan, 2014-15) and the water requirements for drinking and agronomic purposes are almost solely fulfilled from a single river system. The River Indus and its tributaries irrigate nearly all of the arable soils of the arid and semi-arid areas of the Pakistan. However, poor systems of irrigation distribution, a rapidly growing population, recurrent droughts and saline groundwater have all resulted in increased water shortages. Thus Pakistan has a significant water deficit issue owing to the lack of available surface storage reservoirs and ongoing depletion of ground water resources (Kashif et al., 2009). Thus due to the scarcity of fresh water supplies, today untreated waste water is more frequently used for irrigation. However, untreated waste water may contain number of potential contaminants including heavy metals, inorganic salts, organics and pathogens (Qadir et al., 2010). Continuous use of wastewater is bringing the high concentrations of $\mathrm{Cd}$ and elevating its level in the agricultural soil of Pakistan. Cadmium is released in soil environment through different anthropogenic activities such as atmospheric deposition, application of phosphatic fertilizers, pesticides, cement industries and metal industries (Lim et al., 2013; Lee et al., 2013). In particular, the high mobility of heavy metals is a major concern because of the potential for this to result in food chain contamination. Cadmium which exhibits very high mobility compared to other metals such as $\mathrm{Pb}$, has the greatest potential to enter food chain in relatively high concentrations (Khodaverdiloo et al., 2011). Mobile Cd mainly accumulates in aerial plant parts and is transferred to animals and humans when they consume the edible parts of the food crop, especially the leaves of leafy vegetables. Excessive $\mathrm{Cd}$ intake is also a major concern because $\mathrm{Cd}$ accumulates in the body over time (McLaughlin et al., 1999; Kabir et al., 2014).

The contamination of vegetables by heavy metals; especially leafy vegetables like spinach (Spinacea oleracea L.) is a serious issue because of the significance of vegetables as food commodity and as a primary source of proteins, vitamins, iron, calcium and other essential minerals. The concentration of these metals in the edible parts of leafy vegetables depends mainly on the magnitude of soil contamination and the soil quality. Whereas, the innate ability of the plant to tolerate exposure to heavy metals together with the degree of soil contamination determine the overall tolerance of the plant to soil heavy metals (Sikka and Nayyar, 2012). Spinach has a relatively high potential to accumulate heavy metals such as $\mathrm{Cd}$ and $\mathrm{Pb}$ in its leaves and thus high potential to cause adverse human health effects when these leaves are consumed (Chunilall et al., 2004; Intawongse and Dean, 2006). High metal uptake commonly exhibited by spinach may be related to its physical structure. As broad leafy vegetable spinach has a large surface area which allows for both a high rate of transpiration and also a large surface area for the absorption of heavy metals. 
In Pakistan, spinach has been extensively grown in the vicinity of the industrial areas of Faisalabad (Murtaza et al., 2010) and these areas are precisely where the scarcity of freshwater has seen a growing reliance on $\mathrm{Cd}$ contaminated wastewater for irrigation (Qadir et al., 2010). The ingression of heavy metals from wastewater and different other anthropogenic sources is increasing at an alarming rate in soils surrounding peri-urban areas especially in industrial cities of Pakistan. Soil is a sink for these heavy metals which will ultimately reach groundwater, plants, animals and humans. Thus in such areas it is vital to urgently minimize the entry of highly toxic heavy metals such as $\mathrm{Cd}$ in to the food chain and thereby decrease the associated human health risks. One potential way to reduce the entry of $\mathrm{Cd}$ into edible plant parts is via the addition of essential micronutrient like Zn (Koleli et al., 2004). For example, Wu and Zhang (2002) previously investigated the competitive relation between $\mathrm{Cd}$ and $\mathrm{Zn}$ and showed that in theory an antagonistic interaction between $\mathrm{Cd}$ and $\mathrm{Zn}$ existed which could be used to decrease the phytoavailability of $\mathrm{Cd}$ to spinach. Knowledge of contamination of spinach with $\mathrm{Cd}$ from the industrial areas of Faisalabad and use of $\mathrm{Cd}: \mathrm{Zn}$ ratio to ameliorate the toxicity of $\mathrm{Cd}$ in this important vegetable is not yet established. Thus here we practically examine the effect of increasing $\mathrm{Zn}$ concentrations in a $\mathrm{Cd}$ contaminated soil on reducing the levels of $\mathrm{Cd}$ accumulated in the leaves of spinach when cropped on the contaminated soil.

\section{MATERIALS AND METHODS}

Control Soil: The uncontaminated soil used in this study was collected from the Institute of Soil and Environmental Sciences, University of Agriculture Faisalabad, Pakistan and was used as control. The soil was air-dried, ground with wooden roller, and passed through a $2 \mathrm{~mm}$ sieve prior to any physicochemical analyses. A representative soil sub-sample (1 $\mathrm{kg}$ ) was retained for measuring $\mathrm{pH}_{\mathrm{s}}, \mathrm{EC}_{\mathrm{e}}$, lime content $\left(\mathrm{CaCO}_{3}\right)$, organic matter $(\mathrm{OM})$ content, soluble cations and anions, cation exchange capacity (CEC) and phosphorus following standard methods (Page et al., 1982). Particle-size analysis of the soil carried out following hydrometer method (Bouyoucos, 1962) and textural class was designated following the system of International Society of Soil Science. The concentrations of ammonium bicarbonatediethylenetriaminepentaacetic acid (AB-DTPA) extractable $\mathrm{Cd}, \mathrm{Pb}$ and $\mathrm{Zn}$ in soil were also determined with atomic absorption spectrophotometer (AAS, Thermo AA ${ }^{\circledR}$, SolarSeries) (Table 1).

Spiked Soil: The control soil was artificially contaminated with $\mathrm{Cd}$ (3 mg kg-1) using $\mathrm{CdCl}_{2} \cdot 2 \mathrm{H}_{2} \mathrm{O}$. The $\mathrm{Cd}$ contaminated soil was also amended with $\mathrm{Zn}$ at two $\mathrm{Cd} ; \mathrm{Zn}$ ratios of 1:10 (Cd@3 mg kg-1 $\left.+\mathrm{Zn} @ 30 \mathrm{mg} \mathrm{kg}^{-1}\right)$ and 1:100 (Cd@ $\left.3 \mathrm{mg} \mathrm{kg}^{-1}+\mathrm{Zn} @ 300 \mathrm{mg} \mathrm{kg}^{-1}\right)$. The Cd-spiked soil alone and $\mathrm{Cd}$-spiked soil amended with two different concentrations of $\mathrm{Zn}$ were then equilibrated for a 4 weeks at field capacity to allow redistribution of $\mathrm{Cd}$ and $\mathrm{Zn}$ into different soil phases.

Table 1.Selected physiochemical properties of the control soil.

\begin{tabular}{ll}
\hline Soil characteristics & Value \\
\hline Textural class & Sandy clay loam \\
$\mathrm{pH}_{\mathrm{s}}$ & 7.16 \\
$\mathrm{EC}_{\mathrm{e}}\left(\mathrm{dS} \mathrm{m} \mathrm{m}^{-1}\right)$ & 3.25 \\
$\mathrm{SAR}\left(\mathrm{mmol} \mathrm{L}^{-1}\right)^{1 / 2}$ & 1.69 \\
$\mathrm{TSS}\left(\mathrm{mmol}_{\mathrm{c}} \mathrm{L}^{-1}\right)$ & 32.5 \\
$\mathrm{CaCO}_{3}(\%)$ & 1.78 \\
$\mathrm{Organic} \mathrm{matter}(\%)$ & 0.72 \\
$\quad \mathrm{AB}-\mathrm{DTPA}$ extractable & \\
$\mathrm{Cd}\left(\mathrm{mg} \mathrm{kg}^{-1}\right)$ & 0.08 \\
$\mathrm{~Pb}\left(\mathrm{mg} \mathrm{kg}^{-1}\right)$ & 1.25 \\
$\mathrm{Zn}\left(\mathrm{mg} \mathrm{kg}^{-1}\right)$ & 2.45 \\
$\quad$ Total $\left(\mathrm{HNO}_{3} \& \mathrm{HClO}_{4} ; 3: 1\right)$ & \\
$\mathrm{Cd}\left(\mathrm{mg} \mathrm{kg}^{-1}\right)$ & 1.82 \\
$\mathrm{~Pb}\left(\mathrm{mg} \mathrm{kg}^{-1}\right)$ & 13.55 \\
$\mathrm{Zn}\left(\mathrm{mg} \mathrm{kg}^{-1}\right)$ & 27.5 \\
\hline
\end{tabular}

Experimental design: The growth experiment was conducted in the glasshouse at University of Agriculture Faisalabad, Pakistan. Four treatments with three replicates of each treatment were conducted in a completely randomized design (CRD). Metal-spiked soils (10 kg) were filled in glazed pots internally lined with polythene sheet. The recommended dose of NPK fertilizer for spinach (85-62-50) was applied in the form of urea, diammonium phosphate (DAP) and sulfate of potash (SOP). Urea, DAP and SOP were used as the sources of nitrogen, phosphorus and potassium, respectively. The four treatments employed were $\mathrm{T}_{0}\left(\right.$ control (uncontaminated soil)), $\mathrm{T}_{1}(\mathrm{Cd}$ contaminated soil $\left(3 \mathrm{mg} \mathrm{kg}^{-1}\right), \mathrm{T}_{2}\left(\mathrm{Cd}\right.$ contaminated soil $+30 \mathrm{mg} \mathrm{Zn} \mathrm{kg}^{-1}(1: 10$ ratio $)$ and $\mathrm{T}_{3}\left(\mathrm{Cd}\right.$ contaminated soil $+300 \mathrm{mg} \mathrm{Zn} \mathrm{kg}^{-1}(1: 100$ ratio).

Crop husbandry: When the moisture in the pot reached field capacity (measured by weighing soil containing pots regularly until we get moisture in the soil equivalent to field capacity), 10-15 seeds of spinach (Spinacia oleracea L.) were sown in each pot on October 2, 2010. After germination, seedlings were thinned to 5 plants per pot. The uprooted plants were crushed and buried in their respective pots. One third of nitrogen applied as urea and the whole amount of DAP and SOP were incorporated into the pots at the time of sowing. Subsequently, the remaining portions of $\mathrm{N}$ were applied 15 and 25 days after germination in two equal splits. Spinach plants were irrigated with canal water as and when required. After eight week of sowing, the crop was harvested. Subsequently, leaves were washed with deionized water, air-dried and ground to a fine powder in a Wiley mill fitted with stainless steel blades. Effect of Cd:Zn 
concentration on Cd uptake, root and shoot dry weights was investigated.

Analysis: Total metal concentrations in the ground plant materials were determined via an atomic absorption spectrophotometer following a di-acid $\left(\mathrm{HNO}_{3}{ }^{+} \mathrm{HClO}_{4} ; 3: 1\right)$ digestion method (AOAC, 1990). One gram of oven-dried plant sample was taken in a conical flask, kept overnight after adding $5 \mathrm{~mL}$ concentrated nitric acid and $5 \mathrm{~mL}$ of perchloric acid. Next day, again added $5 \mathrm{~mL}$ concentrated $\mathrm{HNO}_{3}$, and digested on a hot plate till solution was clear. After digestion, the material was cooled and made the volume $25 \mathrm{~mL}$ with distilled water and stored in air-tight bottles for the determination of metals with atomic absorption spectrophotometer AAS, (Thermo AA ${ }^{\circledR}$, SolarSeries). The AB-DTPA extracting solution was prepared by dissolving $79.06 \mathrm{NH}_{4} \mathrm{HCO}_{3}$ and $1.97 \mathrm{~g}$ of DTPA in distilled water and making the volume of solution up to one liter. Soil (10 g) was placed in a $250 \mathrm{~mL}$ Erlenmeyer flask, added 20 $\mathrm{mL}$ of freshly prepared extracting solution, shook on reciprocating shaker at 180 cycles per minute for 15 minutes by keeping flasks open (Soltanpour, 1985), filtered and analyzed the extract for metal ions with atomic absorption spectrophotometer (Model Thermo S-Series).

Metal $\left(\mathrm{mg} \mathrm{kg}^{-1}\right)=\underline{\text { metal in extract }\left(\mathrm{mg} \mathrm{L}^{-1}\right)-\text { metal in blank }\left(\mathrm{mg} \mathrm{L}^{-1}\right) \times \mathrm{A}}$ weight of soil (g)

Where A is total volume made of the extract in $\mathrm{mL}$.

Biological Concentration Factor (BCF), Translocation Factor (TF) and Biological Accumulation Coefficient (BAC) of $\mathrm{Cd}$ in spinach were calculated by following equations.

$\mathrm{BCF}=\underline{\text { metal }}_{\text {root }}$ metal $_{\text {soil }} \quad$ (Yoon et al. 2006)

$\mathrm{BAC}=\frac{\text { metal }}{\text { metal }}_{\text {soil }} \quad($ Cui et al., 2007; Li et al., 2007)

$\mathrm{TF}=\underline{\text { metal }}_{\text {metal }_{\text {root }}}$

(Li et al., 2007; Cui et al., 2007)

All data were subjected to statistical treatment following analysis of variance (ANOVA) technique using statistic 8.1 software and treatment means were compared using least significant difference (LSD) (Steel et al., 1997).

\section{RESULTS AND DISCUSSION}

Effect of Cd:Zn ratio on dry matter yield of spinach: The highest shoot dry weight of $5.66 \mathrm{~g} \mathrm{pot}^{-1}$ was observed in the control soil. Relative to the control soil, spinach grown in the $\mathrm{Cd}$ contaminated soil without added $\mathrm{Zn}$ exhibited a decreased shoot dry weight. However, with the application of $30 \mathrm{mg} \mathrm{Zn} \mathrm{kg}^{-1}$ to the $\mathrm{Cd}$ contaminated soil, a slight increase in spinach shoot dry weight was observed (Table 2). However, when the $\mathrm{Zn}$ concentration in $\mathrm{Cd}$ contaminated soil was further increased to $300 \mathrm{mg} \mathrm{Zn} \mathrm{kg}^{-1}$, a reduction in the dry biomass of spinach was observed. At this concentration and a $\mathrm{Cd}: \mathrm{Zn}$ ratio of $1: 100$, the lowest shoot dry weight of $4.72 \mathrm{~g}$ was observed, which corresponded to a $16.6 \%$ decrease in shoot dry weight relative to the control.

A similar variation in spinach root biomass was observed in response to changes in $\mathrm{Cd}: \mathrm{Zn}$ soil ratios. While root dry weight remained highest $\left(0.87 \mathrm{~g} \mathrm{pot}^{-1}\right)$ in control treatment, a significant reduction in root dry biomass was observed when spinach was grown in the $\mathrm{Cd}$ contaminated soil without the addition of $\mathrm{Zn}$. However, amendment with the lower $\mathrm{Zn}$ levels (30 mg kg-1) increased the root dry matter yield relative to the $\mathrm{Cd}$ contaminated soil. However further increase in $\mathrm{Zn}$ concentrations decreased root biomass, so that the lowest root dry weight $\left(0.60 \mathrm{~g} \mathrm{pot}^{-1}\right)$ was observed at a $\mathrm{Cd}: \mathrm{Zn}$ ratio of $1: 100$ which was equivalent to $31.5 \%$ decrease relative to the control treatment.

\section{Table 2. Effect of $\mathrm{Cd}: \mathrm{Zn}$ soil ratio on spinach dry matter} yield $\left(\mathrm{g} \mathrm{pot}^{-1}\right)$.

\begin{tabular}{|c|c|c|}
\hline Treatment & Shoot dry weight & Root dry weight \\
\hline Control & $5.66 a$ & $0.87 \mathrm{a}$ \\
\hline $\mathrm{Cd}\left(3 \mathrm{mg} \mathrm{kg}{ }^{-1}\right)$ & $5.50 \mathrm{ab}(2.83)^{*}$ & $0.83 \mathrm{a}(4.05)$ \\
\hline Cd:Zn (1:10) & $5.58 \mathrm{a}(1.36)$ & $0.85 a(2.68)$ \\
\hline $\mathrm{Cd}: Z n(1: 100)$ & $4.72 b(16.6)$ & $0.60 b(31.5)$ \\
\hline
\end{tabular}

Means sharing similar letter in a row or in a column are statistically non-significant at $\mathrm{P}<0.05$.

*Values in parenthesis are \% increase (+) or decrease (-) over the respective control.

Cadmium is a highly toxic metal that can interfere with both the physiological and metabolic processes of spinach which ultimately results in retardation of growth (Murtaza et al., 2015). In agreement with several previous studies both shoot and root dry matter yield of spinach was decreased here in the $\mathrm{Cd}$ contaminated soil due to the $\mathrm{Cd}$ induced phytotoxicity (Kherbani et al., 2015; Ezhilvannan and Sharavanan, 2015). While a decrease in overall growth of spinach was generally observed upon exposure to $\mathrm{Cd}$, a nonsignificant decrease in the shoot dry matter was observed at a $\mathrm{Cd}: \mathrm{Zn}$ ratio of $1: 10$ compared to the $\mathrm{Cd}$ contaminated treatment. Thus addition of $\mathrm{Zn}$ to the $\mathrm{Cd}$ contaminated soil at the lower $\left(30 \mathrm{mg} \mathrm{kg}^{-1}\right)$ level did not significantly increase the dry matter yield of spinach. However a slight positive effect on the growth was monitored compared to $\mathrm{Cd}$ contaminated soil. Zinc is an important micronutrient which is essential for plant growth. Thus the presence of $\mathrm{Zn}$ at $30 \mathrm{mg} \mathrm{kg}^{-1}$ might have slightly decreased the toxic effect of $\mathrm{Cd}$ by improving overall photosynthesis and chlorophyll content in the spinach (Hassan et al., 2005). The increased reduction in both shoot fresh and dry biomass $\left(\mathrm{g} \mathrm{pot}^{-1}\right)$ at a $\mathrm{Cd}: \mathrm{Zn}$ ratio of 1:100 was probably due to the toxic effect of $\mathrm{Zn}$ alone at this concentration (300 mg kg-1) as indicated in the previous study conducted by Alia et al. (2015). Certainly, there was a 
sharp decrease in all of spinach's the growth parameters at the higher levels of $\mathrm{Zn}$. At higher level, $\mathrm{Zn}$ has previously been reported to cause reductions in both shoot and root biomass through direct toxic effects at higher concentration and also occasionally due to antagonistic interaction in absorption of other nutrient ions necessary for plant growth. The observed decrease at a $\mathrm{Cd}: \mathrm{Zn}$ ratio of $1: 100$ is in agreement with Alia et al. (2015) who reported that application of $\mathrm{Zn}\left(250 \mathrm{mg} \mathrm{kg} \mathrm{kg}^{-1}\right)$ decreased the growth parameters of spinach, which is comparable to the $300 \mathrm{mg}$ $\mathrm{kg}^{-1}$ added here for spinach at which $\mathrm{Zn}$ became a toxic pollutant instead of being as essential nutrient.

Effect of Cd:Zn in the soil on the concentration of Cd and $\mathrm{Zn}$ in the spinach leaves: The $\mathrm{Cd}: \mathrm{Zn}$ ratio in the soil had a significant effect at $\mathrm{P}<0.05$ on the concentration $\left(\mathrm{mg} \mathrm{kg}^{-1}\right)$ of $\mathrm{Cd}$ in the spinach leaves (Table 3 ). Relative to the control, a significant increase in the $\mathrm{Cd}$ concentration of spinach leaves was observed when grown on the $\mathrm{Cd}$ contaminated soil. However, the highest concentration of leaf $\mathrm{Cd}(3.67 \mathrm{mg}$ $\mathrm{kg}^{-1}$ ) was observed at a Cd:Zn ratio of 1:10 (i.e. Cd @ $3 \mathrm{mg}$ $\mathrm{kg}^{-1}$ and $\left.\mathrm{Zn} @ 30 \mathrm{mg} \mathrm{kg}{ }^{-1}\right)$. At the higher $\mathrm{Cd}: \mathrm{Zn}$ ratio of 1:100 (i.e.Cd@ 3 mg kg-1 and Zn@ @ $300 \mathrm{mg} \mathrm{kg}^{-1}$ ), Cd spinach leaf concentrations were significantly decreased $\left(1.96 \mathrm{mg} \mathrm{kg}^{-1}\right)$ relative to both the contaminated soil and that treated with only modest amounts of $\mathrm{Zn}$. Overall, a decrease in the concentration of $\mathrm{Cd}$ in spinach leaves of up to $46.2 \%$ was observed at a $\mathrm{Cd}: \mathrm{Zn}$ ratio of $1: 100$. Concurrent with the significant decrease in $\mathrm{Cd}$ leaf levels at this ratio was significant increase in $\mathrm{Zn}$ leaf concentration. Thus $\mathrm{Zn}$ leaf concentrations were highest $\left(343 \mathrm{mg} \mathrm{kg}^{-1}\right)$ at a $\mathrm{Cd}: \mathrm{Zn}$ ratio of $1: 100$ and decreased to $48.4 \mathrm{mg} \mathrm{kg}^{-1}$ at a $\mathrm{Cd}: \mathrm{Zn}$ ratio of $1: 10$, but were lowest $\left(0.01 \mathrm{mg} \mathrm{kg}^{-1}\right)$ in the control soil which was comparable to the contaminated soil $\left(0.15 \mathrm{mg} \mathrm{kg}^{-}\right.$ $1)$.

Table 3. Concentrations $\left(\mathrm{mg} \mathrm{kg}^{-1}\right)$ of $\mathrm{Cd}$ and $\mathrm{Zn}$ in spinach leaves.

\begin{tabular}{lcc}
\hline Treatment & Cd $\left(\mathbf{m g ~ k g}^{-\mathbf{1}}\right)$ & $\mathbf{Z n ~}\left(\mathbf{m g ~ k g}^{-\mathbf{1}}\right)$ \\
\hline Control & $0.01 \mathrm{c}$ & $0.01 \mathrm{c}$ \\
Cd $\left(3 \mathrm{mg} \mathrm{kg}^{-1}\right)$ & $3.29 \mathrm{a}$ & $0.01 \mathrm{c}$ \\
Cd:Zn $(1: 10)$ & $3.67 \mathrm{a}$ & $48.4 \mathrm{~b}$ \\
Cd:Zn $(1: 100)$ & $1.96 \mathrm{~b}$ & $343 \mathrm{a}$ \\
\hline
\end{tabular}

Means sharing similar letter in a row or in a column are statistically non-significant at $\mathrm{P}<0.05$.

Effect of Cd:Zn in the soil on the concentration of Cd and $\mathrm{Zn}$ in the spinach roots: The ratio of $\mathrm{Cd}: \mathrm{Zn}$ in the soil had a significant $(\mathrm{P}<0.05)$ effect on the concentration of $\mathrm{Cd}$ in the spinach roots (Table 4). Relative to the control, there was a significant increase in the concentration of $\mathrm{Cd}$ in spinach roots when grown in the contaminated soil. However, as observed for shoots, the highest concentration of $\mathrm{Cd}$ (3.14 $\mathrm{mg} \mathrm{kg}$ ) in spinach roots was observed at a $\mathrm{Cd}: \mathrm{Zn}$ ratio of $1: 10$. At the higher $\mathrm{Cd}: \mathrm{Zn}$ ratio of $1: 100, \mathrm{Cd}$ concentrations decreased. Overall a decrease in the concentration of spinach root $\mathrm{Cd}$ of up to $37.2 \%$ was observed at $\mathrm{Cd}: \mathrm{Zn}$ ratio of $1: 100$. As had been observed with shoots, the highest root $\mathrm{Zn}$ concentration ( $350 \mathrm{mg} \mathrm{kg}^{-1}$ ) was observed at a $\mathrm{Cd}: \mathrm{Zn}$ ratio of 1:100 followed by $51.4 \mathrm{mg} \mathrm{kg}^{-1}$ at a $\mathrm{Cd}: \mathrm{Zn}$ ratio of $1: 10$ and the lowest root $\mathrm{Zn}$ concentration was observed in the control (0.01 $\left.\mathrm{mg} \mathrm{kg}^{-1}\right)$.

Table 4. Concentrations $\left(\mathrm{mg} \mathrm{kg}^{-1}\right)$ of $\mathrm{Cd}$ and $\mathrm{Zn}$ in spinach roots.

\begin{tabular}{lcc}
\hline Treatment & Cd $\left(\mathbf{m g ~ k g}^{-\mathbf{1}}\right)$ & Zn $\left(\mathbf{m g ~ k g}^{-\mathbf{1}}\right)$ \\
\hline Control & $0.01 \mathrm{c}$ & $0.02 \mathrm{c}$ \\
$\mathrm{Cd}\left(3 \mathrm{mg} \mathrm{kg}{ }^{-1}\right)$ & $2.96 \mathrm{a}$ & $0.01 \mathrm{c}$ \\
$\mathrm{Cd}: Z n(1: 10)$ & $3.14 \mathrm{a}$ & $51.4 \mathrm{~b}$ \\
$\mathrm{Cd}: Z n(1: 100)$ & $1.97 \mathrm{~b}$ & $350 \mathrm{a}$ \\
\hline
\end{tabular}

Means sharing similar letter in a row or in a column are statistically non-significant at $\mathrm{P}<0.05$.

Effect of Cd:Zn on biological accumulation coefficient $(B A C)$, biological concentration factor (BCF) and translocation factor (TF) of $\boldsymbol{C d}$ : The soil $\mathrm{Cd}: \mathrm{Zn}$ ratio had a pronounced influence on a range of $\mathrm{Cd}$ bioaccumulation and transfer coefficients for spinach (Table 5). Relative to the control, the $\mathrm{Cd}$ biological concentration factor $(\mathrm{BCF})$ for $\mathrm{Cd}$ increased significantly when spinach was grown on the $\mathrm{Cd}$ contaminated soil. While the lowest level of applied Zn (30 $\mathrm{mg} \mathrm{kg}^{-1}$ soil) increased BCF, the highest level of applied $\mathrm{Zn}$ (300 $\mathrm{mg} \mathrm{kg}^{-1}$ soil) significantly decreased BCF. Similar behaviors were also observed for both the biological accumulation coefficient (BAC) and the translocation factor (TF) of $\mathrm{Cd}$ in spinach. Consistently, at the lower level of

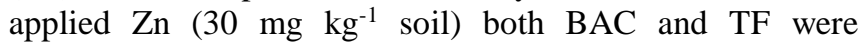
increased but at the higher applied $\mathrm{Zn}$ concentration both BAC and TF were decreased relative to the values observed in the Cd contaminated soil.

Table 5. Effect of Cd:Zn on biological accumulation coefficient (BAC), biological concentration factor (BCF), translocation factor (TF) of Cd.

\begin{tabular}{lccc}
\hline Treatment & BCF & BAC & TF \\
\hline Control & 0.01 & 0.01 & 0.01 \\
Cd $\left(3 \mathrm{mg} \mathrm{kg}^{-1}\right)$ & 0.99 & 1.10 & 1.11 \\
Cd:Zn $(1: 10)$ & 1.05 & 1.22 & 1.17 \\
Cd:Zn $(1: 100)$ & 0.66 & 0.65 & 0.99 \\
\hline
\end{tabular}

As expected from simple mass balance, the concentration of $\mathrm{Cd}$ in spinach leaves increased as the level of $\mathrm{Cd}$ in the soil increased. With the addition of $\mathrm{Cd}$ to the soil, it is expected that both the soluble and exchangeable pools of $\mathrm{Cd}$ in the soil would also increase and that this would ultimately increase plant uptake leading to diminished growth and development of spinach (Sikka and Nayyar, 2012). While addition of $\mathrm{Zn}$ at the lower level (1:10 ratio) did not significantly affected the concentration of $\mathrm{Cd}$ in spinach plants compared to those plants grown in the $\mathrm{Cd}$ 
contaminated soil, there was a slight increase in the concentration of $\mathrm{Cd}$ with the addition of $\mathrm{Zn}$ at a 1:10 ratio, i.e. $30 \mathrm{mg} \mathrm{Zn} \mathrm{kg}^{-1}$ soil. This could be attributed to increased synthesis of phytochelatins (PCs) by spinach. Cadmium induced toxicity results in more significant formation of $\mathrm{Cd}$ forming Cd-PC complexes (Rauser, 2000). Such complexes are able to better sequester $\mathrm{Cd}$ in the vacuole thereby reducing $\mathrm{Cd}$ translocation to the shoot. However, with the addition of increasing amounts of $\mathrm{Zn}$ to the soil it is likely that $\mathrm{Zn}-\mathrm{PC}$ complexes are competitively formed in larger amounts thus increasing the concentration of free $\mathrm{Cd}$ which results in the increased translocation of $\mathrm{Cd}$ from root to shoot. Moreover, since the $\mathrm{Cd}$ is chemically similar to $\mathrm{Zn}$, it may be taken up by the roots through $\mathrm{Zn}$ transporters. At low level of $\mathrm{Zn}$ in growth medium, $\mathrm{Zn}$ transporters are not fully loaded and $\mathrm{Cd}$ is more likely to be transported by $\mathrm{Zn}$ transporter. Above these are possible explanations to the occurrence of slightly high $\mathrm{Cd}$ concentrations in the leaves of spinach at a $1: 10$ ratio of $\mathrm{Cd}$ and $\mathrm{Zn}$.

In contrast, at the higher $\mathrm{Zn}$ concentration (300 mg kg-1) there was a significant decrease in the concentration of $\mathrm{Cd}$. Previous studies have indicated that one option to decrease $\mathrm{Cd}$ accumulation in plants is to effectively improve plant $\mathrm{Zn}$ nutrition (Qiu et al., 2005; Aravind et al., 2009). Since both $\mathrm{Zn}$ and $\mathrm{Cd}$ have almost identical ionic radii, the addition of $\mathrm{Zn}$ might result in active competition with $\mathrm{Cd}$ for the same membrane binding sites and transport systems, thereby resulting in reduced $\mathrm{Cd}$ accumulation in spinach. The interaction of $\mathrm{Cd}$ with $\mathrm{Zn}$ in plants is based on the substitution of $\mathrm{Cd}$ with $\mathrm{Zn}$ and decreasing the concentration of $\mathrm{Cd}$ to below phytotoxic levels in spinach leaves. The application of higher soil $\mathrm{Zn}$ concentrations decreased soil $\mathrm{Cd}$ phytoavailability and subsequently decreased the uptake of $\mathrm{Cd}$ by the plants. This is in agreement with the antagonistic relationship previously reported (Hassan et al., 2005). Results of the present study indicated that there was a sharp decrease in the concentration of $\mathrm{Cd}$ in spinach leaves at 1:100 $\mathrm{Cd}: \mathrm{Zn}$ ratio corresponding to a $46.2 \%$ decrease in the concentration of $\mathrm{Cd}$ compared to a $\mathrm{Cd}: \mathrm{Zn}$ ratio of $1: 10$.

AB-DTPA extractable $\mathrm{Cd}$ and $\mathrm{Zn}$ concentration in postharvest soil analysis: The ratio of $\mathrm{Cd}: \mathrm{Zn}$ in the soil had a highly significant $(\mathrm{P}<0.05)$ effect on the concentration of AB-DTPA extractable $\mathrm{Cd}$ and $\mathrm{Zn}$ in the post-harvest soil samples (Table 6). Relative to the control, there was a significant increase in the concentration of AB-DTPA extractable $\mathrm{Cd}\left(0.62 \mathrm{mg} \mathrm{kg}^{-1}\right)$ in post-harvest soil sample of $\mathrm{Cd}$ contaminated soil. However, a significant decrease in the concentration of $\mathrm{Cd}$ was observed at a $\mathrm{Cd}: \mathrm{Zn}$ ratio of 1:10 . At the higher Cd:Zn ratio of 1:100 (i.e. Cd @ $3 \mathrm{mg} \mathrm{kg}^{-1}$ and $\mathrm{Zn}$ @ $300 \mathrm{mg} \quad \mathrm{kg}^{-1}$ ) AB-DTPA extractable Cd concentrations increased and the highest concentration of $0.87 \mathrm{mg} \mathrm{kg}^{-1}$ was monitored. The concentration of ABDTPA extractable $\mathrm{Zn}$ was the highest $\left(57.9 \mathrm{mg} \mathrm{kg}^{-1}\right)$ at the higher $\mathrm{Cd}: \mathrm{Zn}$ ratio of 1:100 followed by $3.64 \mathrm{mg} \mathrm{kg}^{-1}$ at a
Cd:Zn ratio of 1:10 (i.e. Cd @ $3 \mathrm{mg} \mathrm{kg}^{-1}$ and Zn@ $30 \mathrm{mg}$ $\mathrm{kg}^{-1}$ ) and lowest in the control treatment.

Table 6. AB-DTPA extractable concentrations (mg kg-1) of $\mathrm{Cd}$ and $\mathrm{Zn}$ in post-harvest soil samples.

\begin{tabular}{lcc}
\hline Treatment & Cd $\left(\mathbf{m g ~ k g}^{-\mathbf{1}}\right)$ & $\mathbf{Z n ~}\left(\mathbf{m g ~ k g}^{\mathbf{- 1}}\right)$ \\
\hline Control & $0.09 \mathrm{~d}$ & $0.14 \mathrm{c}$ \\
$\mathrm{Cd}\left(3 \mathrm{mg} \mathrm{kg}^{-1}\right)$ & $0.62 \mathrm{~b}$ & $0.15 \mathrm{c}$ \\
$\mathrm{Cd}: Z n(1: 10)$ & $0.45 \mathrm{c}$ & $3.64 \mathrm{~b}$ \\
$\mathrm{Cd}: Z n(1: 100)$ & $0.87 \mathrm{a}$ & $57.9 \mathrm{a}$ \\
\hline
\end{tabular}

Means sharing similar letter in a row or in a column are statistically non-significant at $\mathrm{P}<0.05$.

From the above result it is evident that with the increase of soil contamination there was an increase in the concentration of AB-DTPA extractable $\mathrm{Cd}$. The concentration of ABDTPA extractable $\mathrm{Cd}$ decreased significantly with the addition of lower level of $\mathrm{Zn}$ in soil (1:10), reflecting an increased uptake of $\mathrm{Cd}$ by spinach leaves as the values of $\mathrm{BAC}$ and $\mathrm{BCF}$ increased in the present study. However, higher concentration of $\mathrm{Zn}$ (i.e. $300 \mathrm{mg} \mathrm{kg}^{-1}$ ) at 1:100 Cd:Zn significantly increased the concentration of AB-DTPA extractable $\mathrm{Cd}$ in soil samples compared to $\mathrm{Cd}$-spiked soil. At higher level of $\mathrm{Zn}, \mathrm{Zn}$ transporters are fully occupied and cannot take up $\mathrm{Cd}$ resulting in the decreased accumulation of $\mathrm{Cd}$ in spinach and increased AB-DTPA extractable soil Cd.

Conclusion: At the highest level of $\mathrm{Zn}$ applied in this study (300 $\mathrm{mg} \mathrm{kg}^{-1}$ ) an antagonistic relation between $\mathrm{Cd}$ and $\mathrm{Zn}$ was observed. At the lower level of applied Zn (30 mg kg-1) $\mathrm{Cd}$ toxicity was alleviated and the dry matter yield of spinach was increased. However, the lower level of applied $\mathrm{Zn}$ in combination with a contaminated $\mathrm{Cd}$ soil $\left(3 \mathrm{mg} \mathrm{kg}{ }^{-1}\right)$ did not decrease the $\mathrm{Cd}$ leaf concentrations. A higher level of $\mathrm{Zn}\left(300 \mathrm{mg} \mathrm{kg}^{-1}\right)$ corresponding to a $\mathrm{Cd}: \mathrm{Zn}$ ratio of 1:100 did however decrease the $\mathrm{Cd}$ leaf concentrations in spinach by $46.2 \%$ relative to the $\mathrm{Cd}: \mathrm{Zn}$ ratio of $1: 10$. This study highlights the importance of choosing a suitable $\mathrm{Cd}: \mathrm{Zn}$ ratio which can effectively decrease the damaging effects of $\mathrm{Cd}$ on plant growth and simultaneously minimize $\mathrm{Cd}$ uptake in to edible parts of plants when grown in Cd stressed soils.

Acknowledgments: This study was funded by the Higher Education Commission (HEC), Islamabad, Pakistan. The authors also thank the extensive and critical comments of the anonymous reviewers who have certainly increased the quality of the final published manuscript.

\section{REFERENCES}

Alia, N., S. Khan, M. Said, K. Salma, A. Sadia, S. Sadaf, A. Toqeer and S. Miklas. 2015. Toxicity and bioaccumulation of heavy metals in spinach (Spinacia oleracea) grown in a controlled environment. Int. J. Environ. Res. Public Health 12:7400-7416.

AOAC. 1990. Official and tentative methods of analysis. Association of Official Agricultural Chemists. AOAC Inc, Arlington. 
Aravind, P., M.N.V. Prasad, P. Malec, A. Waloszek and K. Strzaka 2009. Zinc protects Ceratophyllum demersum L. (free-lum demersumotecte) against reactive oxygen species induced by cadmium. J. Trace Elements Med. Biol. 23:50-60.

Chunilall, V., A. Kindness and S.B. Jonnalagadda. 2004. Heavy metal uptake by spinach leaves grown on contaminated soil with lead, mercury, cadmium and nickel. J. Environ. Sci. Health 38:473-81.

Cui, S., Q. Zhou and L. Chao. 2007. Potential hyper-accumulation of $\mathrm{Pb}, \mathrm{Zn}, \mathrm{Cu}$ and $\mathrm{Cd}$ in endurant plants distributed in an old smeltery, northeast China. Environ. Geol. 51:1043-1048.

Ezhilvannan, D. and P.S. Sharavanan. 2015. Influences of cadmium on nutrient contents of bengal gram (Cicer arietinum L.). Am. J. Environ. Eng. Sci. 2:28-31.

Hassan, M.J., G. Zhang, F. Wu, K. Wei and Z. Chen. 2005. Zinc alleviates growth inhibition and oxidative stress caused by cadmium in rice. J. Plant Nutr. Soil Sci. 162:255-261.

Intawongse, M. and J.R. Dean. 2006. Uptake of heavy metals by vegetables grown on contaminated soil and their bioavailability in the human gastrointestinal tract. Food Addit. Contam. 23:36-48.

Kabir, E.R., Z. Sheikh, T. Tabassum and S. Khan. 2014. Impact of cadmium exposure on human health with a focus on Bangladesh. Eur. J. Toxicol. Sci. 3:1-33.

Kashif, S.R., M. Akram, M. Yaseen and S. Ali. 2009. Studies on heavy metals status and their uptake by vegetables in adjoining areas of Hudiara drain in Lahore. Soil Environ. 28:7-12.

Kherbani, N., N. Abdi and H. Lounici. 2015. Effect of cadmium and zinc on growing barley. J. Environ. Prot. 6:160-172.

Khodaverdiloo, H., S.G. Dashtaki and S. Rezapour. 2011. Lead and cadmium accumulation potential and toxicity threshold determined for land cress (Barbarea verna) and spinach (Spinacia oleracea L.). Int. J. Plant Prod. 5:271-280.

Koleli, N., S. Eke and I. Cakmak. 2004. Effect of zinc fertilization on cadmium toxicity in durum and bread wheat grown in zinc deficient soil. Environ. Pollut. 131:453-459.

Lee, S.S., J.E. Lim, S.A.M. Abd El-Azeem, B. Choi, S.E. Oh, D.H. Moon and Y.S. Ok. 2013. Heavy metal immobilization in soil near abandoned mines using eggshell waste and rapeseed residue. Environ. Sci. Pollut. Res. 20:1719-1726.

Li, M.S., Y.P. Luo and Z.Y. Su. 2007. Heavy metal concentrations in soils and plant accumulation in a restored manganese mineland in Guangxi, South China. Environ. Pollut. 147:168175.

Lim, J.E., M. Ahmad, A.R.A. Usman, S.S. Lee, W.T. Jeon, S.E. Oh, J.E. Yang and Y.S. Ok. 2013. Effects of natural and calcined poultry waste on $\mathrm{Cd}, \mathrm{Pb}$ and As mobility in contaminated soil. Environ. Earth Sci. 69:11-20.
McLaughlin, M.J., D.R. Parker and J.M. Clarke. 1999. Metals and micronutrients - food safety issues. Field Crop Res. 60:143163.

Murtaza, G., W. Javed, A. Hussain, A. Wahid, B. Murtaza, and G. Owens. 2015. Metal uptake via phosphate fertilizer and city sewage in cereal and legume crops in Pakistan. Environ. Sci. Pollut. Res. 22:9136-9147.

Page, A.L., R.H. Miller and D.R. Keeny. 1982. Methods of Soil Analysis (Part 2): Chemical and microbiological properties. Agron. 9, SSSA, Madison, WI, USA.

Pakistan Economic Survey. 2014-15. Economic Adviser's Wing, Finance Division, Government of Pakistan, Islamabad, Pakistan.

Qadir, M., D. Wichelns, L. Raschid-Sally, P.G. McCornick, P. Drechsel, A. Bahri and P.S. Minhas. 2010. The challenges of wastewater irrigation in developing countries. Agric. Water Manage. 97:561-568.

Qiu, Z.Z., Z.Y. Guan and C.Y. Long. 2005. Effect of zinc on cadmium uptake by spring wheat (Triticum aestivum L.): Long time hydroponic study and short time $\mathrm{Cd}$ tracing study. J. Zhejiang Univ. Sci. 6:643-648.

Rauser, W.E. 2000. The role of thiols in plants under metal stress. In: C. Brunold, H. Rennenberg, L.J. De Kok, I. Stulen and J.C. Davidian (eds.), Sulphur Nutrition and Sulphur Assimilation in Higher Plants: Molecular, biochemical and physiological aspects. Paul Haupt, Bern, pp.169-183.

Sikka, R. and V. Nayyar. 2012. Cadmium accumulation and its effects on uptake of micronutrients in Indian mustard grown in a loamy sand soil artificially contaminated with cadmium. Commun. Soil Sci. Plant Anal. 43:672-688.

Soltanpour, P.N. 1985. Use of AB-DTPA soil test to evaluate elemental availability and toxicity. Commun. Soil Sci. Plant Anal. 16:323-338.

Steel, R.G.D., J.H. Torrie and D.A. Dickey. 1997. Principles and Procedures of Statistics: A biometrical approach, $3^{\text {rd }}$ Ed. McGraw Hill Book Co. Inc.

Wu, F.B. and G.P. Zhang. 2002. Differences between barley cultivars in seedling growth and in uptake of cadmium and nutrients under various $\mathrm{Cd}$ levels. China J. Appl. Ecol. 13:1595-1599.

Yoon, J., X. Cao, Q. Zhou and L.Q. Ma. 2006. Accumulation of Pb, $\mathrm{Cu}$, and $\mathrm{Zn}$ in native plants growing on a contaminated Florida site. Sci. Total Environ. 368:456-464.

Zhu, Y.G., S.E. Smith and F.A. Smith. 2001. Plant growth and cation composition of two cultivars of spring wheat (Triticum aestivum L.) differing in $\mathrm{P}$ uptake efficiency. J. Exp. Bot. 52:1277-1282. 